\title{
Effectiveness of reduced doses of flumioxazin herbicide at weed control in direct sow onions
}

\section{Efectividad del herbicida flumioxazin a dosis reducida para el control de malezas en cebollas de siembra directa}
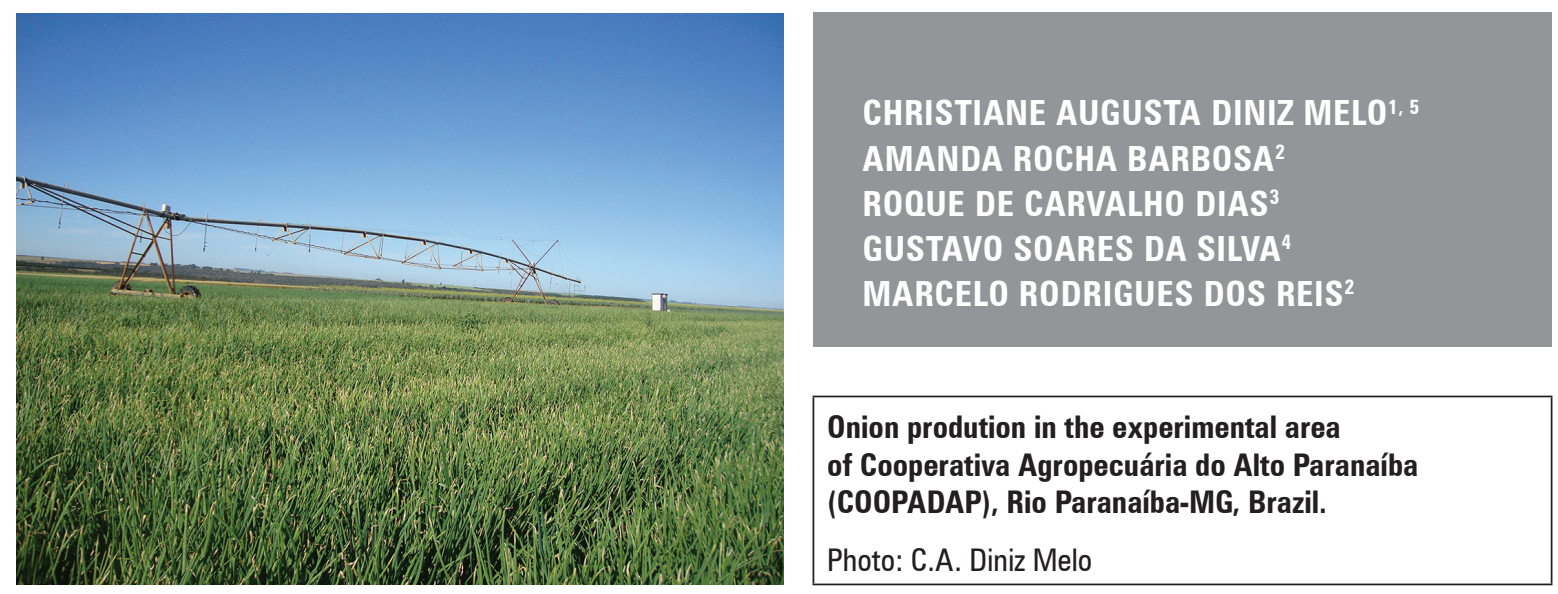

\section{ABSTRACT}

The recommended application of most herbicides in onion crops is after transplanting seedlings with four true leaves. In the direct sowing system, this recommendation is considered late; an alternative management is the application of reduced doses starting with a true leaf. The objective of this study was to evaluate the use of reduced doses of flumioxazin in the early phenological stages of onions on bulb yield. Two field experiments were installed, and five doses of flumioxazin (5, 10, 15, 20, and $\left.25 \mathrm{~g} \mathrm{ha}^{-1}\right)$ were applied in three phenological stages $\left(1^{\text {st }}, 2^{\text {nd }}\right.$, and $1^{\text {st }}+3^{\text {rd }}$ true leaf); weed control was carried out. The results demonstrated the efficacy of reduced doses of flumioxazin on onion crop in the early stages. The dose of $20 \mathrm{~g} \mathrm{ha}^{-1}$ showed use potential in the two experiments for the cvs. Perfecta and Sirius, enabling reductions of 77 to $88 \%$ of the commercial dose recommended for onions established with seedling transplanting. The application of flumioxazin in the $2^{\text {nd }}$ leaf reduced commercial productivity and was ineffective in the control of weeds. The application in the $1^{\text {st }}+3^{\text {rd }}$ leaf, despite being an effective control, caused greater phytotoxicity and, therefore, reduced commercial productivity. The best strategy for weed management is $20 \mathrm{~g} \mathrm{ha}^{-1}$ flumioxazin applied to onion plants when they reach the true first leaf stage.

\footnotetext{
Additional key words: Allium cepa; bulb yield; herbicide; phytotoxicity.

1 Universidade Federal do Triângulo Mineiro, Iturama Campus, Iturama (Brazil). ORCID Melo, C.A.D.: 0000-00016385-2153; ORCID Reis, M.R.: 0000-0002-9940-5838

2 Universidade Federal de Viçosa, Rio Paranaíba Campus, Rio Paranaíba (Brazil). ORCID Barbosa, A.R.: 0000-0002-42737399

3 Universidade Estadual Paulista "Júlio de Mesquita Filho", Faculty of Agricultural Sciences, Botucatu (Brazil). ORCID Dias, R.C.: 0000-0001-5433-5373

4 Universidade de São Paulo, Colégio de Agricultura Luiz de Queiroz, Piracicaba (Brazil). ORCID Silva, G.S.: 0000-00033267-7254

5 Corresponding author: christiane.melo@uftm.edu.br
} 


\section{RESUMEN}

Se recomienda en la mayoría de las veces la aplicación de herbicidas en cultivos de cebolla después del trasplante, cuando las plántulas tienen cuatro hojas verdaderas. En el sistema de siembra directa esta recomendación se considera tardía y una alternativa es la aplicación de menores dosis desde la aparición de una hoja verdadera de la cebolla. El objetivo de este estudio fue evaluar dosis reducidas de flumioxazina en estadios fenológicos tempranos de cebolla sobre el rendimiento de los bulbos. Se realizaron dos experimentos de campo y se aplicaron cinco dosis de flumioxazina $\left(5,10,15,20\right.$ y $\left.25 \mathrm{~g} \mathrm{ha}^{-1}\right)$ en tres estadios fenológicos ( $1^{\mathrm{a}}, 2^{\mathrm{a}}$ y $1^{\mathrm{a}}+3^{\mathrm{a}}$ hoja verdadera), manteniendo un control con deshierbe manual. Los resultados demostraron la eficacia de dosis reducidas de flumioxazina en el cultivo de cebolla en estadios fenológicos tempranos. La dosis de $20 \mathrm{~g} \mathrm{ha}^{-1}$ mostró un potencial en los dos experimentos para cultivares Perfecta y Sirius, lo que permite reducirse entre el 77 y $88 \%$ de la dosis comercial recomendada en plántulas cebolla trasplantada. La aplicación de flumioxazina en la $2^{\mathrm{a}}$ hoja redujo la productividad comercial y fue ineficaz en el control de malezas. La aplicación en la $1^{a}+3^{a}$ hoja, a pesar de ser efectiva en el control, provocó una mayor fitotoxicidad y, por lo tanto, redujo la productividad comercial. La mejor estrategia para el manejo de malezas es 20 $\mathrm{g}$ ha ${ }^{-1}$ de flumioxazina aplicada a las plantas de cebolla cuando alcanzan la etapa de la primera hoja verdadera.

Palabras clave adicionales: Allium cepa; rendimiento de bulbos; herbicida; fitotoxicidad.

Received for publication: 16-04-2018 Accepted for publication: 29-03-2019

INTRODUCTION

Onions (Allium cepa L.) are very sensitive to interference from weeds. Onion cultivation is characterized by low soil cover because of the low plant size, little production of leaves, which are cylindrical and erect, and slow initial growth of the crops. These aspects result in low competitiveness and allow the germination and growth of weeds at practically any stage of development (Reis et al., 2017).

In terms of crops with a high technological level, this crop presents a high cost of production; it is common to find high levels of fertility in this production system, with systematic irrigation and intensive tillage, which promote high populations of weeds (Pereira, 2008). The management of weeds in onion crops is an important variable in the definition of productivity since this crop is negatively affected by competition with weeds. Onion productivity decreases drastically with the interference of weeds, which may reach $100 \%$ loss in the commercial production of bulbs (Jean-Simon et al., 2012; Qasem, 2005). Thus, it is necessary to use control measures during the critical period of interference prevention, which is long in the onion crop and varies from 40 to $100 \mathrm{~d}$ (Soares et al., 2003; Qasem, 2006).

Among the control methods, chemical management of weeds is widely used in this crop because of greater yield in large areas, high efficiency and lower cost. However, it requires knowledge on the use and behavior of herbicides in the soil and their selectivity to the crop, especially because the onion is highly sensitive to these products (Qasem, 2006; Uygur et al., 2010; Carvalho et al., 2014).

In Brazil, there are few herbicide options for onion use. Linuron has been the standard for chemical weed control in onion crops since the 1980s. However, the control exerted by this herbicide has been unsatisfactory because, after 10-15 d, post-emergence herbicide applications, which may toxify the crop, and/ or manual weeding are required, increasing the cost of production.

Flumioxazin ( $N$-[7-fluoro-3,4-dihydro-3-oxo-4-prop2 -ynyl-2H-1,4-benzoxazin-6-yl]cyclohex1-ene-1,2-dicarboxamide) may be an alternative for herbicide use in onion crops. It is an active non-ionic ingredient that exhibits low solubility in water (1.79 $\mathrm{mg} \mathrm{L}^{-1}$ at $25^{\circ} \mathrm{C}$ ) (Ferrell et al., 2005) and a vapor pressure of $2.41 \times 10^{-6} \mathrm{~mm} \mathrm{Hg}$ at $22^{\circ} \mathrm{C}$, indicating a low volatilization potential (Rodrigues and Almeida, 2011). It may present half-life of $17.6 \mathrm{~d}$ in the soil (PPDB, 2018) and undergoes degradation through hydrolysis and microorganism activity (Alister et al., 2008). Accordingly, flumioxazin presents little aggression 
to the environment; however, there are reports that, in some areas of Alliaceas in Alto Paranaíba, damage occurred through phytotoxicity, mainly with excess rainwater or irrigation and the use of high doses or doses at an inappropriate vegetative stage, making farmers afraid to use it.

Flumioxazin is registered for pre-emergence applications on weeds, 2-3 d after seedling transplanting (Agrofit, 2018). However, in the direct sowing system, applications on onion plants at the true four-leaf stage, the recommended stage for most herbicides, is considered late and ineffective against the advanced development of weeds.

Because of these problems, an alternative is to use reduced doses at the initial stages of the crop ( $1^{\text {st }}$, $2^{\text {nd }}$, and $1^{\text {st }}+3^{\text {rd }}$ true leaf) since recommended doses for the onion vary from 60 to $90 \mathrm{~g} \mathrm{ha}^{-1}$ ai. The objective of this study was to evaluate the efficacy of reduced doses of flumioxazin, applied in the initial phenological stages of the onion crop in terms of bulb productivity.

\section{MATERIAL AND METHODS}

Two experiments were carried out under field conditions. Experiment 1 was set in the experimental area of Cooperativa Agropecuária do Alto Paranaíba (COOPADAP), located in the municipality of Rio Paranaíba, Minas Gerais, Brazil, in a clayey Dystroferric Red Oxisol from February to July of 2015. Experiment 2 was installed in an area of commercial production on the Santo Amaro Farm, located in the municipality of Rio Paranaíba, in a dystrophic Red Oxisol with a clay texture from February to June of 2016.

In both experiments, direct sowing was used with four double lines per bed, where one million and two hundred thousand seeds per hectare were distributed. In experiment 1, cv. Perfecta was sown and, in experiment 2, cv. Sirius was used.

The planting fertilization in experiment 1 was $800 \mathrm{~kg}$ ha- of $\mathrm{P}_{2} \mathrm{O}_{5}, 50 \mathrm{~kg} \mathrm{ha}^{-1}$ of $\mathrm{N}$ and $50 \mathrm{~kg} \mathrm{ha}^{-1}$ of $\mathrm{K}_{2} \mathrm{O}$. At 20 and $40 \mathrm{~d}$ after emergence, topdressing fertilization was carried out with $75 \mathrm{~kg} \mathrm{ha}^{-1}$ of $\mathrm{N}$ and $125 \mathrm{~kg} \mathrm{ha}^{-1}$ of $\mathrm{K}_{2} \mathrm{O}$. In experiment 2, $950 \mathrm{~kg} \mathrm{ha}^{-1}$ of $\mathrm{P}_{2} \mathrm{O}_{5}, 40 \mathrm{~kg} \mathrm{ha}^{-1}$ of $\mathrm{N}$ and $30 \mathrm{~kg} \mathrm{ha}^{-1}$ of $\mathrm{K}_{2} \mathrm{O}$ were used. At 25 and $50 \mathrm{~d}$ after emergence, topdressing fertilization was carried out with $55 \mathrm{~kg} \mathrm{ha}^{-1}$ of $\mathrm{N}$ and $130 \mathrm{~kg} \mathrm{ha}^{-1}$ of $\mathrm{K}_{2} \mathrm{O}$. The fertilization differences between the areas were based on the chemical analyses of the soils and nutrition demand of the cultivars.

In both experiments, a randomized complete block design was used, with treatments arranged in a $5 \times 3+1$ factorial scheme, with four replicates. The first factor corresponded to the reduced doses of flumioxazin $\left(5,10,15,20\right.$ and $\left.25 \mathrm{~g} \mathrm{ha}^{-1}\right)$, and the second factor was the phenological stage of the onion on which the herbicide was applied $\left(1^{\text {st }}, 2^{\text {nd }}\right.$, and $1^{\text {st }}+3^{\text {rd }}$ true leaf), as well as weed control. The parcels with the treatment $1^{\text {st }}+3^{\text {rd }}$ true leaf received two applications of flumioxazin in the two phenological stage of the onion at the five doses described.

The dimensions of each experimental plot were 1.5 (four double lines) $\times 4 \mathrm{~m}$, and the two central double lines were considered as the useful area, minus 0.5 $\mathrm{m}$ at each end of the plot. For the application of flumioxazin (Flumyzin 500 - active ingredient concentration $500 \mathrm{~g} \mathrm{~kg}^{-1}$ - wettable powder formulation), a $\mathrm{CO}_{2}$ backpack sprayer pressurized at 2 bar equipped with a bar with three flat jet tips, (fan type) 110.02, spaced at $0.5 \mathrm{~m}$ was used at $0.5 \mathrm{~m}$ above the soil with a volume of $200 \mathrm{~L} \mathrm{ha}^{-1}$.

At 15, 30 and $45 \mathrm{~d}$ after application (DAA) of the herbicide, counted from the application on the $1^{\text {st }}$ true leaf stage, phytotoxicity evaluations were performed using a visual scale from 0 to $100 \%$, where $0 \%$ represents the absence of symptoms and $100 \%$ is the death of the plant, and visual evaluation of the weed control (Gazziero, 1995). At 30 and 60 DAA, stand evaluations were performed by counting plants in two linear meters at three delimited points in each plot.

At 150 and $130 \mathrm{~d}$ after sowing, the onion was harvested in Experiments 1 and 2, respectively. One hundred plants were harvested in the useful area of each plot, and the commercial (Classes 2, 3, 4, and 5) and non-commercial (Classes 0 and 1 ) and total bulb yields were classified and estimated. The classification was performed according to the Companhia de Entrepostos e Armazéns Gerais de São Paulo (CEAGESP) commercial scale, based on the equatorial diameter of the bulbs in Class $0(<1.5 \mathrm{~cm})$, Class 1 ( 1.5 to $3.5 \mathrm{~cm}$ ), Class $2(3.5$ to $5.0 \mathrm{~cm}$ ), Class 3 (5.0 to 7.0 $\mathrm{cm})$, Class $4(7.0$ to $9.0 \mathrm{~cm})$, and Class $5(>9.0 \mathrm{~cm})$.

The data were submitted to analysis of variance by the $\mathrm{F}$ test $(P \leq 0.05)$, and the means were plotted in figures with standard error. The experiments were analyzed separately. The software Sisvar 5.6 and Sigmaplot 10.0 were used for this. 


\section{RESULTS AND DISCUSSION}

The onion toxicity was affected by the phenological stage of the crop, reduced doses of flumioxazin and cultivar. In experiment 1 , at $15 \mathrm{DAA}$, the plants presented $15 \%$ injury on average (Fig. 1A), characterized by chlorotic spots on the leaves. In experiment 2 , the application performed on the $2^{\text {nd }}$ leaf caused increased phytotoxicity as the doses increased up to a maximum of $25 \%$ (Fig. 1D). At the time of this evaluation, the application on the $3^{\text {rd }}$ leaf stage had not yet been performed because the onion plants still had two true leaves, explaining the equal results with the applications performed in the stages $1^{\text {st }}$ and $1^{\text {st }}+3^{\text {rd }}$ leaf.

According to Cavaliere (2015), in order to minimize the toxicity caused by herbicides in onions, fractionation and escalation of doses have been carried out and have contributed to increased selectivity in onions, especially in the initial stages of growth of direct sowing plants. However, even with the reduction of doses, phytotoxicity may occur, as verified in the present study. In Turkey, onion phytotoxicity from herbicides is also a serious problem and, even when splitting the recommended dose of oxyfluorfen, injures have been found in plants (Uygur et al., 2010).

In the visual evaluations performed at 30 and $45 \mathrm{DAA}$ in experiment 1 , higher phytotoxicity was observed for the plants submitted to application on the $1^{\text {st }}+3^{\text {rd }}$ leaf, followed by application on the $2^{\text {nd }}$ leaf and on the $1^{\text {st }}$ true leaf of the crop (Fig. $1 \mathrm{~B}$ and $1 \mathrm{C}$ ). In experiment 2 at $30 \mathrm{DAA}$, the application on the $1^{\text {st }}+3^{\text {rd }}$ leaf caused greater phytotoxicity in the plants than at other stages, with reduction of the symptoms at 45 DAA, regardless of the treatments (Fig. 1E and 1F).

The increase in phytotoxicity in relation to the phenological stages of the crop may evidence that the tolerance of the onion to this herbicide decreases with the age of the plant and the number of applications $\left(1^{\text {st }}+3^{\text {rd }}\right.$ leaf). This is probably related to the increase in the number of leaves and, consequently, the leaf area for interception of the product at those initial stages of the onion planted via direct sowing. For oxyfluorfen, a herbicide of another chemical group, but with the same mechanism of action as flumioxazin, studies have shown that symptoms decreased with the age of the transplanted onion, which is due to the increase in the wax content in the leaves (Carvalho et al., 2014). These authors verified greater phytotoxicity when oxyfluorfen was applied at $14 \mathrm{~d}$ after transplanting (DAT) when compared to the application at 28 DAT.

At $60 \mathrm{DAA}$, the onion plants completely recovered from toxicity, regardless of the phenological stage (data not shown). This recovery was due to the low or absence of translocation of the herbicide in the plant, acting as a contact product. Thus, the new emitted leaves were free of toxicity symptoms. Durigan et al. (2005) found that, at 49 DAA of flumioxazin, onion plants recovered from severe initial toxicity when the application was made on the $5^{\text {th }}-6^{\text {th }}$ leaf of the transplanted crop.

Weed control in both experiments at 15 DAA was satisfactory in the plots where application was made on the $1^{\text {st }}$ leaf (Fig. 2A and 2D). The application on the first true leaf of the onion provided weed control at an early stage of development, ensuring control effectiveness even at the smallest evaluated dose. The predominant species in experiment 1 were Nicandra physalodes (L.) Gaertn., Galinsoga parviflora Cav., Portulaca oleracea L., Sonchus oleraceus L., and Ageratum conyzoides L. In experiment 2 , the predominant weeds were Eleusine indica (L.) Gaertn, Commelina benghalensis L., N. physalodes and Gamochaeta coarctata (Willd.) Kerguélen.

The application on the second leaf of the onion satisfactorily controlled only with the dose of $10 \mathrm{~g} \mathrm{ha}^{-1}$ in experiment 1 at $15 \mathrm{DAA}$ (Fig. 2A). In the other evaluations (30 and $45 \mathrm{DAA}$ ), this treatment was ineffective (Fig. 2B and 2C). The application of reduced doses of flumioxazin when the crop had two true leaves was not effective probably because the weeds in the area were already more developed. In experiment 2 , this application stage provided acceptable control from 30 DAA, regardless of the applied dose (Fig. 2E and 2F).

At 45 DAA in experiment 1 , the applications on the $1^{\text {st }}$ and $1^{\text {st }}+3^{\text {rd }}$ leaves maintained control of over $90 \%$ with the $10 \mathrm{~g} \mathrm{ha}^{-1}$ dose of flumioxazin (Fig. 2C). Besides controlling weeds early in the area when applied at first leaf of the onion, the additional application on the third leaf extended the residual effect of the herbicide, which also had a pre-emergence action on the weeds. In experiment 2 , the application in the three stages provided satisfactory control $(>80 \%$ ) (Gazziero, 1995), particularly on the $1^{\text {st }}$ and $3^{\text {rd }}$ leaves, which maintained control near 100\% regardless of the dose (Fig. 2F). 


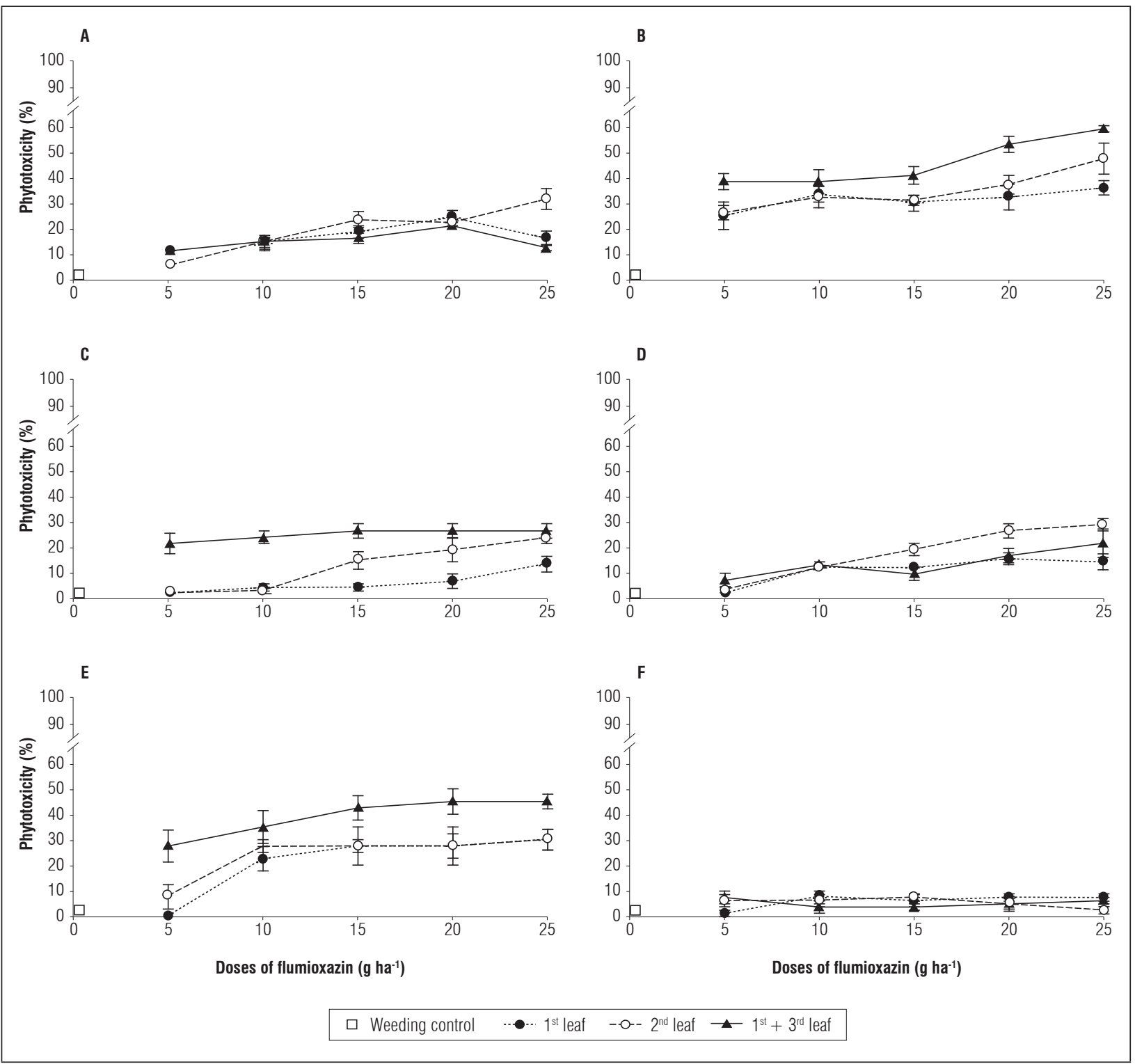

Figure 1. Phytotoxicity of onion plants evaluated at 15, 30 and $45 \mathrm{~d}$ after application of reduced doses of flumioxazin in experiment 1 (A, B, C) and experiment $2(D, E, F)$, respectively.

In experiment 1, the stand was not altered by the application of reduced doses of flumioxazin in relation to the weeding control in the two evaluated periods (Fig. $3 \mathrm{~A}$ and $3 \mathrm{~B}$ ). In experiment 2 , the stand was reduced only with the highest dose $\left(25 \mathrm{~g} \mathrm{ha}^{-1}\right)$ at 30 DAA in the three application stages and, at 60 DAA, in the $1^{\text {st }}$ and $1^{\text {st }}+3^{\text {rd }}$ leaf stages (Fig. 3C and 3D). The reduction in the number of onion plants was also verified by Ferreira et al. (2000) with an application of oxyfluorfen $\left(0.192 \mathrm{~kg} \mathrm{ha}^{-1}\right)$ at $19 \mathrm{~d}$ after sowing, reducing the initial stand by $22.6 \%$.
Because the onion crop is very sensitive to herbicides, it is likely to suffer toxicity and be suppressed, especially in the early stages of development. Thus, depending on the dose and growth stage of the crop, phytotoxicity may be severe, irreversibly impairing the growth of the plants, leading to death and, therefore, reducing the initial population of the crop. Onion production fields established by direct sowing usually present a highly variable plant population, which was also observed in the experimental plots. 


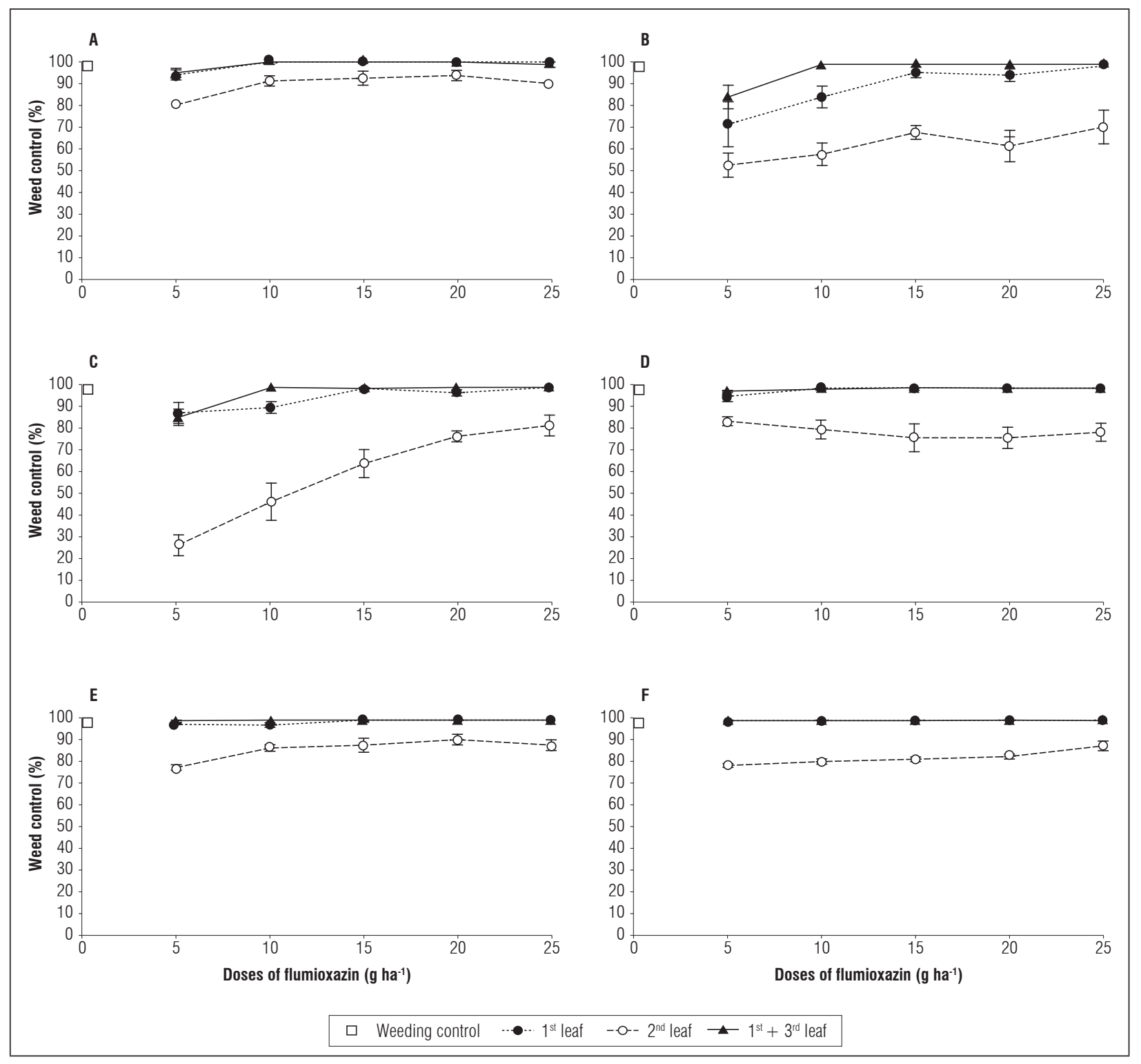

Figure 2. Weed control evaluated at 15, 30 and $45 \mathrm{~d}$ after the application of reduced doses of flumioxazin in experiment 1 (A, $B, C)$ and experiment 2 (D, E, F), respectively.

The stand verified in the two experiments was different in the absence of herbicide (Fig. 3), which contributed to the difference in bulb yield observed in the two experiments (Fig. 4). The lowest number of plants per area reduced intraspecific competition, resulting in bulbs with a larger diameter and weight.

The application of flumioxazin on the $2^{\text {nd }}$ and $1^{\text {st }}+3^{\text {rd }}$ leaves increased, in most doses, the bulb yield of 'Perfecta' non-commercial bulbs (Fig. 4A). The application at the first leaf was equal to or lower than the control, up to $15 \mathrm{~g} \mathrm{ha}^{-1}$, increasing the productivity of bulbs with a diameter less than $3.5 \mathrm{~cm}$ in the two highest doses. In experiment 2 , the productivity of non-commercial bulbs was similar in the absence and presence of reduced doses of flumioxazin, except for the $20 \mathrm{~g} \mathrm{ha}^{-1}$ dose applied at the $1^{\text {st }}$ true leaf of the crop, which was lower than the control without an application (Fig. 4 D). Intoxication caused by herbicides may result in reduced crop growth and reduced 

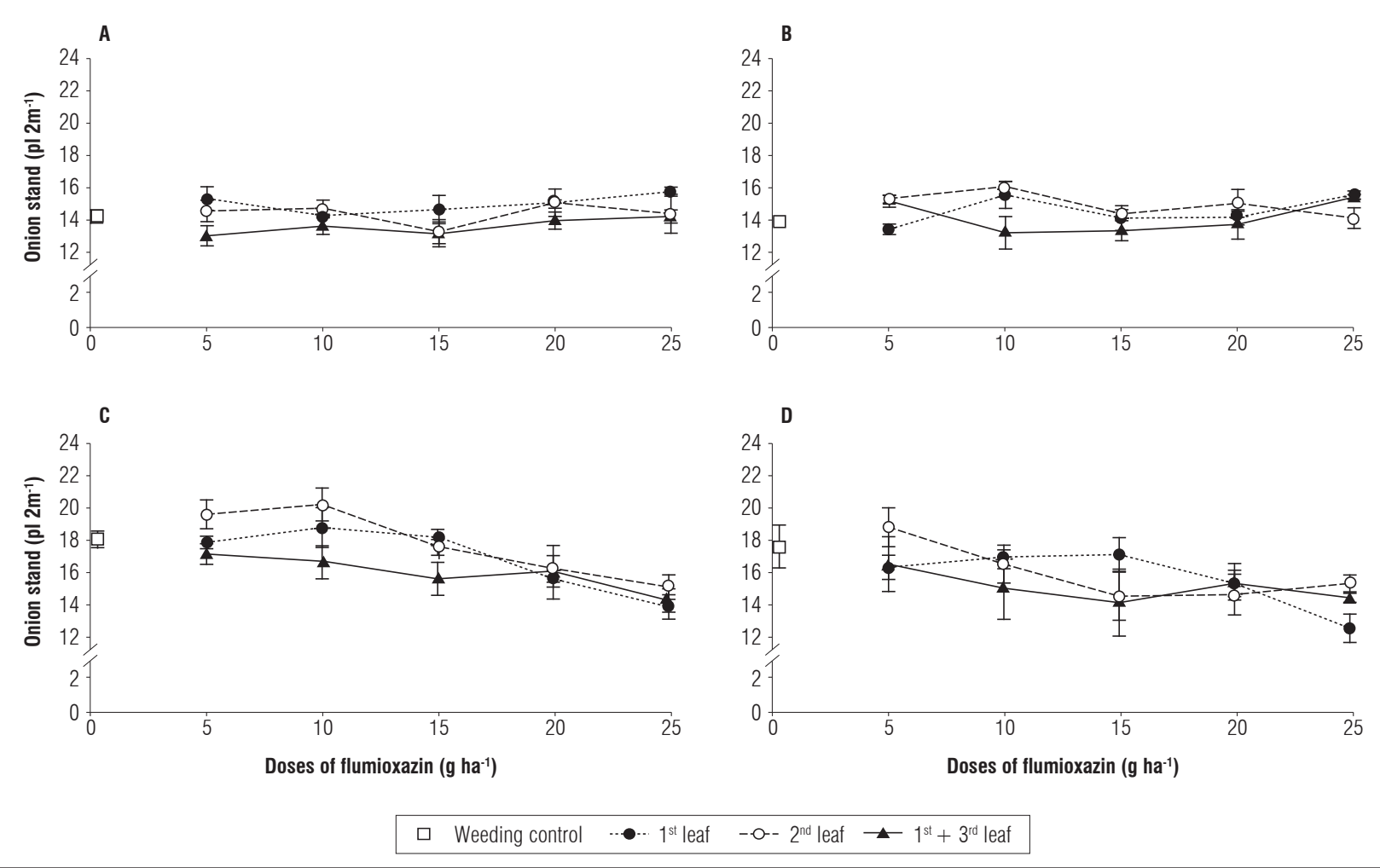

Figure 3. Onion stand evaluated at 30 and $60 \mathrm{~d}$ after the application of reduced doses of flumioxazin in experiment 1 (A, B) and experiment 2 (C, D), respectively.

quantity and quality of the products harvested (Robinson, 2008), even with the application of reduced doses.

The commercial and total yields in experiment 1 presented the same behavior, with emphasis on the application in the first leaf, which was superior to the other phenological stages up to the dose of 20 $\mathrm{g} \mathrm{ha}^{-1}$. The dose of $25 \mathrm{~g} \mathrm{ha}^{-1}$ of flumioxazin applied on the $1^{\text {st }}+3^{\text {rd }}$ leaf reached productivity similar to the first leaf stage. However, in this experiment, the application of flumioxazin reduced the total and commercial productivity by at least $10 \mathrm{t} \mathrm{ha}^{-1}$, as compared to the absence of herbicide (Fig. 4B and 4C). The cultivars presented different tolerances to flumioxazin, where 'Perfecta' - experiment 1 was less tolerant than 'Sirius' - Experiment 2 (Fig. 1). This fact contributed to the effect of the herbicide on the reduction of commercial and total bulb productivity and to the increase of the productivity of non-commercial bulbs, in relation to the weeding control in experiment 1 .
This differential tolerance can be attributed to different foliar waxiness (Ferreira and Costa, 1982) in the two cultivars, which needs to be investigated. According to the technical information from the seed company, both cultivars have good waxiness; however, it is necessary to evaluate the thickness and composition of the cuticle and the amount of wax present in the leaves of the two cultivars to better explain the influence of these characteristics on the differential tolerance to flumioxazin and others herbicides applied post-emergence.

In experiment 2 , starting with the $15 \mathrm{~g} \mathrm{ha}^{-1}$ dose, a difference was found in commercial and total productivity between the stages, with superiority found in the application on the first leaf in comparison to the others. For the control without herbicides, the application on the $2^{\text {nd }}$ leaf reduced the commercial and total productivity, the application on the $1^{\text {st }}+3^{\text {rd }}$ leaf was similar in all the doses and the application on the first leaf was similar up to the dose of $20 \mathrm{~g} \mathrm{ha}^{-1}$ and higher at the dose of $25 \mathrm{~g}$ 


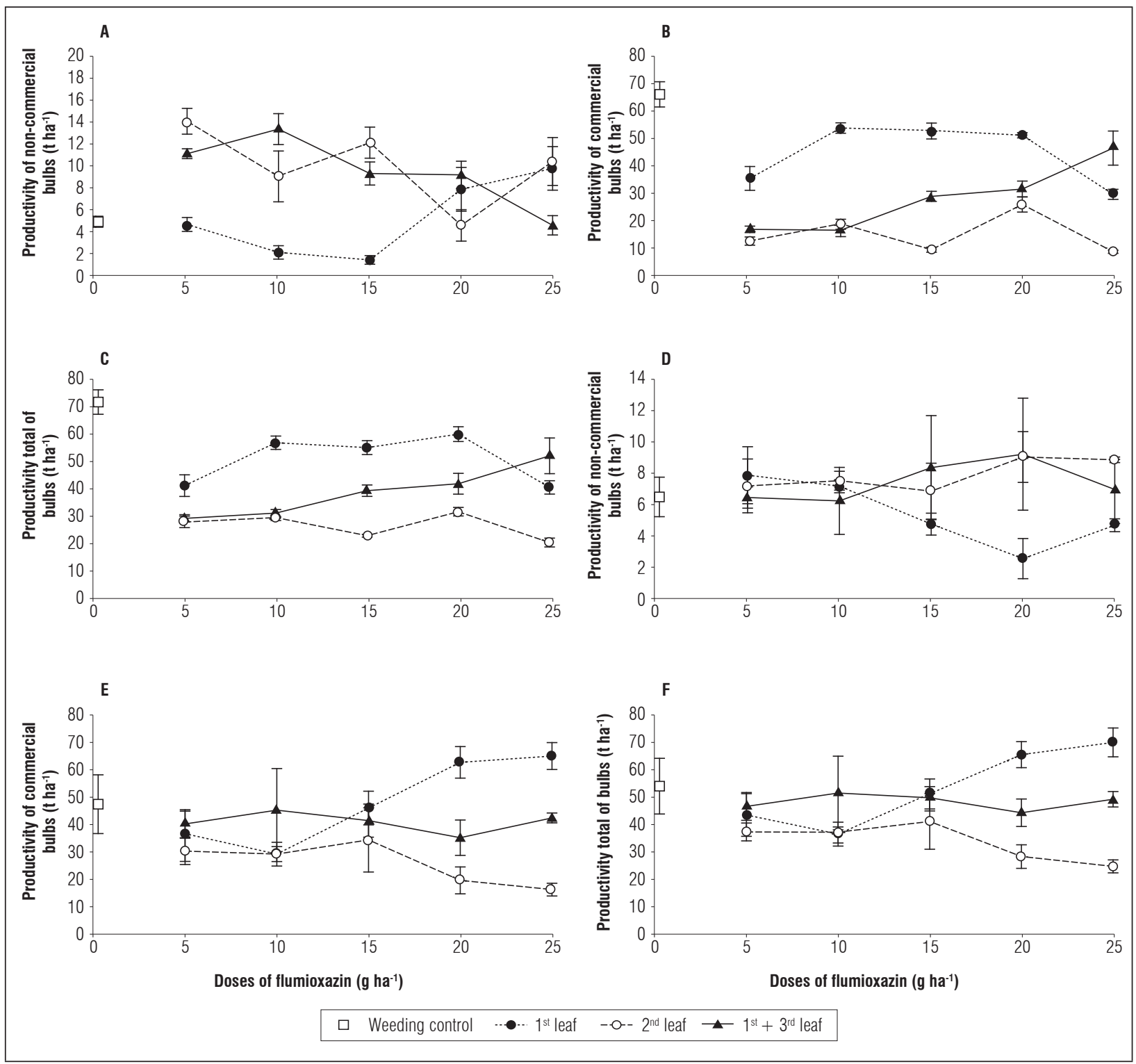

Figure 4. Productivity of non-commercial, commercial and total bulbs of onion plants submitted to reduced doses of flumioxazin at different phenological stages in experiment 1 (A, B, C) and experiment 2 (D, E, F), respectively.

$\mathrm{ha}^{-1}$ (Fig. 4E and 4F). In this experiment, it was evidenced that the use of reduced doses of flumioxazin may guarantee productivity equal to or even higher than the weeding control, depending on the dose applied and the phenological stage of the crop. In Iran, the use of $75 \%$ of the recommended dose of oxyfluorfen provided quality and bulb production comparable to the absence of herbicide according to a study by Abbaszadeh et al. (2014).
The results evidence the efficacy of reduced doses of flumioxazin in onion crops at early stages $\left(1^{\text {st }}, 2^{\text {nd }}\right.$ and $3^{\text {rd }}$ true leaf). The dose of $20 \mathrm{~g} \mathrm{ha}^{-1}$ showed use potential in the two experiments for 'Perfecta' and 'Sirius', enabling a reduction of $77 \%$ to $88 \%$ of the commercial dose recommended for onions planted with seedling transplanting. In addition, because of the lack of information in the literature on the behavior of flumioxazin in soil in tropical conditions, 
this reduction in the dose reduces the potential risks of environmental contamination.

\section{CONCLUSIONS}

The application of flumioxazin on the $2^{\text {nd }}$ leaf reduced commercial productivity and was ineffective at controlling weeds. The application on the $1^{\text {st }}+3^{\text {rd }}$ leaf, although effective in the control, caused greater phytotoxicity and, therefore, reduced commercial productivity. The best strategy for weed management was $20 \mathrm{~g} \mathrm{ha}^{-1}$ of flumioxazin applied to the onion plants when they reached the true first leaf stage.

\section{ACKNOWLEDGEMENT}

The authors thank the Coordenação de Aperfeiçoamento de Pessoal de Nível Superior (CAPES) and Fundação de Amparo à Pesquisa do Estado de Minas Gerais (FAPEMIG) for the scholarship they granted and the Cooperativa Agropecuária do Alto Paranaíba (COOPADAP) and Santo Amaro Farm for their financial and technical support.

Conflict of interests: this manuscript was prepared and reviewed with the participation of the authors, who declare that there exists no conflict of interest that puts at risk the validity of the presented results.

\section{BIBLIOGRAPHIC REFERENCES}

Abbaszadeh, A., M. Dejam, S.S. Khaleghi, and H. Hasanzadeh. 2014. Effect of transplanting date and reduced doses of oxyfluorfen herbicide on weed control, yield and quality of onion (Allium cepa L.) in south of Iran. Indian J. Agric. Res. 48(6), 453-458. Doi: 10.5958/0976-058X.2014.01329.8

Agrofit. 2018. Sistema de Agrotóxicos Fitossanitário. In: Ministério da Agricultura, Pecuária e Abastecimento do Brasil, http://extranet.agricultura.gov.br/agrofit_cons/principal_agrofit_cons; consulted: January, 2018.

Alister, C., S. Rojas, P. Gómez, and M. Kogan. 2008. Dissipation and movement of flumioxazin in soil at four field sites in Chile. Pest Manage. Sci. 64(5), 579-583. Doi: $10.1002 /$ ps.1533

Carvalho, D.R., M.F.P. Lima, F.C.L. Freitas, M.G.O. Silva, P.R.R. Rocha, and L.C. Grangeiro. 2014. Eficiência do oxyfluorfen no controle de plantas daninhas na cultura da cebola transplantada irrigada por gotejamento.
Rev.Agro@mbiente On-line 8(1), 127-133. Doi: 10.18227/1982-8470ragro.v8i1.1553

Cavaliere, S.D. 2015. Matointerferência. Árvore do conhecimento: cebola. In: Agência Embrapa de Informação Tecnológica, http://www.agencia.cnptia. embrapa.br/gestor/cebola/arvore/CONT000gn9eurvp02wx5ok0liq1mqz0umhli.html; consulted: November, 2017.

Durigan, J.C., M.R.M. Silva, and A.A.P.M. Azania. 2005. Eficácia e seletividade do herbicida flumioxazin aplicado em pré-emergência na cultura transplantada da cebola. Rev. Bras. Herb. 4(3), 11-17. Doi: 10.7824/rbh. v4i3.33

Ferreira, P.V. and C.P. Costa. 1982. Efeito da cerosidade foliar na reação de variedades de cebola (Alium cepa L.) a herbicidas de pós-emergência. Planta Daninha 5(2), 29-35. Doi: 10.1590/S0100-83581982000200005

Ferreira, L.R., J.C. Durigan, M.G.C. Churata-Masca, F.A. Ferreira, and A.A. Silva. 2000. Seletividade e eficácia da aplicação sequencial de oxyfluorfen e de ioxynil-octanoato, em semeadura direta de cebola. Planta Daninha 18(1), 9-50. Doi: 10.1590/S0100-83582000000100004

Ferrell, J.A., W.K. Vencill, K. Xia, and T.L. Grey. 2005. Sorption and desorption of flumioxazin to soil, clay minerals and ion-exchange resin. Pest Manage. Sci. 61(1), 40-46. Doi: 10.1002/ps.956

Gazziero, D.L.P. 1995. Procedimentos para instalação, avaliação e análise de experimentos com herbicidas. Sociedade Brasileira da Ciência Das Plantas Daninhas (SBCPD), Londrina, Brazil.

Jean-Simon, L., J.B. Mont-Gerard, and J.J. Sander. 2012. Effect of early season weed competition duration on onion yield. P. Fl. St. Hortic. Soc. 125, 226-228.

Pereira, W. 2008. Manejo e controle de plantas daninhas em hortaliças, pp. 603-658. In: Vargas, L. and E.S. Roman (eds.). Manual de manejo e controle de plantas daninhas. $2^{\text {nd }}$ ed. Embrapa Trigo; Passo Fundo, Brazil.

PPDB, Pesticide Properties DataBase. 2018. Flumioxazin Ref: S 53482. https://sitem.herts.ac.uk/aeru/ppdb/ en/Reports/335.htm; consulted: January, 2018.

Qasem, J.R. 2005. Critical period of weed competition in onion (Allium cepa L.) in Jordan. Jordan J. Agric. Sci. 1(1), 32-42.

Qasem, J.R. 2006. Chemical weed control in seedbed sown onion (Allium cepa L.). Crop Prot. 25(6), 618-622. Doi: 10.1016/j.cropro.2005.09.008

Reis, M.R., C.A.D. Melo, and A.C.L.P. Assis. 2017. Manejo integrado de plantas daninhas em cebola. pp. 179-200. In: Nick, C. and A. Borém (eds.). Cebola: do plantio a colheita. Editora UFV, Viçosa, Brazil.

Robinson, D.E. 2008. Atrazine accentuates carryover injury from mesotrione in vegetable crops. Weed Technol. 22(4), 641-645. Doi: 10.1614/WT-08-055.1 
Rodrigues, B.N. and F.S. Almeida. 2011. Guia de herbicidas: contribuicao para uso adequado em plantio direto $\mathrm{e}$ convencional. $6^{\text {th }}$ ed. Edição dos Autores, Londrina, Brazil.

Soares, D.J., R.A. Pitelli, L.T. Braz, R. Gravena, and R.E.B. Toledo. 2003. Períodos de interferência das plantas daninhas na cultura da cebola (Allium cepa) transplantada. Planta Daninha 21(3), 387-396. Doi: 10.1590/S0100-83582003000300006

Uygur, S., R. Gürbüz, and F.N. Uygur. 2010. Weeds of onion fields and effects of some herbicides on weeds in Cukurova region, Turkey. Afr. J. Biotechnol. 9(42), 7037-7042. 